\title{
Exploring Gamification in Management Education for Sustainable Development
}

\author{
Per-Anders Langendahl ${ }^{1}$, Matthew Cook ${ }^{2}$, Cecilia Mark-Herbert ${ }^{3 *}$ \\ ${ }^{1}$ Department of Economics, Swedish University of Agricultural Sciences, Uppsala, Sweden \\ ${ }^{2}$ Faculty of Science, Technology, Engineering \& Mathematics School of Engineering \& Innovation Open University, \\ Milton Keynes, UK \\ ${ }^{3}$ Department of Forest Products, Swedish University of Agricultural Sciences, Uppsala, Sweden \\ Email: *cecilia.mark-herbert@slu.se
}

How to cite this paper: Langendahl, P.-A., Cook, M., \& Mark-Herbert, C. (2017). Exploring Gamification in Management Education for Sustainable Development. Creative Education, 8, 2243-2257. https://doi.org/10.4236/ce.2017.814154

Received: September 28, 2017 Accepted: November 14, 2017 Published: November 17, 2017

Copyright (C) 2017 by authors and Scientific Research Publishing Inc. This work is licensed under the Creative Commons Attribution International License (CC BY 4.0).

http://creativecommons.org/licenses/by/4.0/

\begin{abstract}
Interdisciplinary approaches are sought in academia as a means to help resolve aspects of unsustainability. In management education, one of many challenges that relate to interdisciplinary working is the development and reinforcement of disciplinary working in teaching sessions. Indeed, perspectives on sustainable development from different disciplines can be brought into teaching activities and presented to students. However, taking different perspectives into education require students to be actively engaged. Drawing on the novel approach known as gamification, this paper explores how it can be used to elevate students' engagement in management education for sustainable development. Gamification is a broad concept, which has been used in multiple settings such as marketing to promote actor engagement. Using case study research, a case was developed to illustrate the use of gamification in an education management context. Findings show how gamification can be used in teaching to increase motivation and engagement among students. The paper concludes that gamification may offer a pedagogic approach to elevate students' engagement in management education for sustainable development and to promote multi-disciplinary working.
\end{abstract}

\section{Keywords}

Gamification, Interdisciplinary Approach, Learning, Management Education, Pedagogics, Sustainable Development, Student Active Learning

\section{Introduction}

Sustainable development is a subject of growing interest in society. Multiple actors working for, for example, research and policy institutions, NGOs and businesses 
seek new approaches to address sustainability challenges, such as climate change, environmental pollution and depletion of natural resources. Drawing on research in social sciences, realists such as Rockström et al. (2009) account for sustainable development as a progressive process towards predefined goals, e.g. 2 degree Celsius. In contrast, constructivist perspectives suggest that sustainable development constitutes multiple, complex and ongoing processes where destinations are unknown (Guy \& Farmer, 2001; Guy, 2006; Guy \& Shove, 2000). Independent of approach, realist or constructivist, sustainability challenges and associated pathways to more sustainable states are uncertain, multiple and diverse. The complexity suggests that interdisciplinary approaches are needed to progressively shape and modulate sustainable development trajectories.

Interdisciplinary working is promoted in academic (and industry) contexts to develop initiatives that may help to resolve sustainability challenges. Interdisciplinary working in education is understood as teaching approaches that bring two or more academic disciplines together in education for sustainable development (Brooks \& Ryan, 2008). Longhurst (2014) identifies that education for sustainable development is widely present in many programmes in higher education, and educators in such contexts need to engage and foster students learning in such contexts. This paper draws on a novel approach known as gamification, defined by Deterding et al. (2011) as the use of game elements in non-game contexts, to explore how it can be used as means to engage students in management education for sustainability. It also explores the potential to promote interdisciplinary working in such contexts.

The paper has the following structure. First, a literature review introduces a broad perspective on pedagogy in terms of theories and concepts of how teaching and learning proceed in practice. The notion of interdisciplinary working for sustainable development is then introduced followed by the gamification concept and associated game elements. An analytical framework is developed from literature to analyze gamification in management education for sustainable development (Wiek et al., 2011). Second, method and approach to this study is presented and findings from an empirical case presented. Third, gamification in management education for sustainable developed is discussed, including its potential to promote interdisciplinary working in such contexts. The paper concludes the insights gained from this study.

\section{Approach and Method}

This study has an inductive approach and commenced with a thorough literature review on gamification in education to identify relevant theoretical concepts and the research forefront on educational use of gamification. The literature review identifies multiple game elements and their deployment in education, which are presented in Section 3.3 and 3.4. A perspective on pedagogy was also applied to develop a framework for analysing the use of gamification in education. An empirical study was conducted subsequently in which the analytical 
framework was used to explore gamification in a higher education setting. The selected empirical case is an advanced course on sustainable marketing management at the Swedish University of Agricultural science. This course was selected as it focuses on management education for sustainable development and involves aspects of multidisciplinary work. In education for sustainable development, generic competencies related to identification, analysis and communication, point to the needs for active student learning (Wiek et al., 2011). The authors of this paper are actively engaged and participate in this course, which enabled access to a rich set of data and insights in the pedagogical processes. The empirical case was analysed to illustrate how gamification in management education for sustainable development, including how gamification may promote interdisciplinary working in such context.

\section{Literature Review and Analytical Framework}

This section presents a brief literature review teaching and learning for sustainable development is followed by the idea of gamification in educational settings. An analytical framework to analyze gamification in educational settings is developed subsequently.

\subsection{Teaching and Learning}

Pedagogy is concerned with theories and concepts of how teaching and learning proceed in practice. In their study on how teaching and learning proceed in practice, Biggs and Tang (2011) explore the role of, and interaction between, teacher and students. There are broadly three classical approaches to teaching and learning (Biggs \& Tang, 2011):

1) Teachers display information (e.g. performing a lecture) and students absorb the information, e.g. via note taking

2) Teachers explain concepts (e.g. lecture or seminar) and students develop skills to understand these, e.g. via critical reflection

3) Students engage with learning activities (e.g. individual or group projects) and teacher support them, e.g. via supervision

This framework of how teaching and learning proceed in practice implies different roles and interactions in education settings between teacher and students. It suggests that the role of teacher and students shifts between different forms of activeness. The teacher can be active in terms displaying information whereby students become somewhat passive recipients. In contrast, students can also have more active roles via exploration and critical reflection whereby teachers act as supporter or facilitator. Seen this way, teaching and learning can be described as co-creational process, where both teacher and learners play major roles. How students engage in learning activities are therefore important. Biggs and Tang (2011) delineate two distinct approaches to learning, these are surface and deep learning.

The surface approach to learning involves a low level engagement in learning 
activities, e.g. memorizing facts. For example, students may absorb information presented to them, learn selected content and memorize these to give an impression of understanding. As such, learning gained from the surface approach includes the ability to memories and paraphrase content. Knowledge gained from surface approaches to learning relates to Bloom's taxonomy (1956) and can be classified as declarative knowledge. This includes knowledge about things that can be expressed verbally or in other symbolic form.

Deep approaches, on the other hand, require a higher level of engagement in learning activities whereby the students achieve a deeper understanding. Learning gained from deep approaches includes the ability to memories and paraphrase content as well as abilities to explain, apply and critically reflect on knowledge gained. Knowledge gained from deep approaches to learning relates to functional knowledge in Bloom's taxonomy (1956). This includes knowledge that can be used by the learner to inform action. For example, a professional practitioner may use theory to inform decisions on what to do in a professional context, e.g. an engineer building a bridge.

Indeed, finding effective pedagogic approaches is a priority for higher education practitioners seeking to maintain and further develop high quality teaching. The objective is to establish conditions for effective pedagogics in educational settings that promote students to engage in deep approaches to learning and gain functional knowledge. Bloom (1956), Biggs and Tang (2011) and Wiek et al. (2011) help us see different approaches to learning depending on what kind of learning outcome that is desired. We now turn to the notion of interdisciplinary working in teaching and learning for sustainable development.

\subsection{Interdisciplinary Working for Sustainable Development}

There are numerous definitions and accounts of interdisciplinary working (Brooks \& Ryan, 2008; Gibbons et al., 1994; Wiek et al., 2011). In simple terms, such approaches are often distinguished from intra disciplinary working-situations when disciplines work together to generate knowledge using a common scientific approach. For example, there has been talk of a "climate science" which encompasses social and natural sciences. In contrast, inter disciplinary working is when disciplines work together on a particular topic of interest but do not seek to develop a common scientific approach. Thus the power of such approaches is in the pluralist application of various perspectives and the varied and multiple insights which can be generated. In no way does this presuppose that disciplines are working on a common problem. Rather, different disciplinary perspectives generate variegated insights founded on different problems and inferred resolutions. In such situations, disciplines work in pluralistic fashion to create a rich picture.

Interdisciplinary working in education for sustainable development is also a subject of a growing literature (Brooks \& Ryan, 2008; Orr, 2002). In management education, one of many challenges to interdisciplinary working is the devel- 
opment and reinforcement of disciplinary working in academia and operationally, in teaching sessions. Open up teaching sessions to interdisciplinary working where two or more disciplines offers plurality of perspectives may therefore be a key challenge to overcome. This paper explores such challenges of interdisciplinary working by drawing on a novel concept, gamification, and its potential as pedagogic approach to promote interdisciplinary working for sustainable development. We now turn to the literature on gamification in education.

\subsection{Gamification and Game Elements}

A widely used definition developed by Deterding et al. (2011) frames gamification as the use of game elements in non-game contexts. Following this definition, game elements are attributes (e.g. challenges, stories and scoreboards) that motivate and engage players of games to keep playing. Gamification is the process of applying game elements in non-game contexts, e.g. marketing and health initiatives. For example, firms use game elements, e.g. point systems, to develop their customer loyalty programs, e.g. frequent flyer programs. Another example is various mobile applications that promote healthy lifestyles by making health-related activities fun. For example, zombies, run!, is a mobile application targeted to runners to make running fun. As such, gamification is applied in various contexts such as education, health, business and sustainability. By implementing game elements, gamification initiatives in these contexts often aim to influence people and promote desirable actions and behavior, for example, when they exercise running, shop, teach and learn. In many instances, gamification is deployed to motivate people to become actively engaged, e.g. to engage activities associated with healthy lifestyle.

A key component in gamifications is the game elements. A variety of game elements are articulated in literature (Deterding et al., 2011; Dicheva et al., 2015; Erenli, 2013; Hamari et al., 2014; Lee \& Hammer, 2011; Stott \& Neustaedter, 2013). Drawing on this literature, game elements are categorised in terms of surface elements, underlying dynamics and game experience. Surface elements are visual and tangible game attributes, e.g. points and leader boards. Underlying dynamic encapsulates game like conditions that create some form of dynamic, e.g. an overarching story, challenges and a sense of progression. Game experience is attributes that create game like experience for those in involved in a gamified activity, e.g. competition, a sense of fun or enjoyment.

Surface elements (e.g. point systems) are arguably the most common type of game element deployed in gamification initiatives (Hamari et al., 2014). These elements are typically used for the purpose of quantifying and visualising individuals' performances and achievements. For example, many firms have successfully deployed gamification as part of their marketing strategies to engage customers in loyalty programmes, e.g. frequent-flyer. In such instances, customers earn points through buying products or services and are rewarded for their efforts. Surface elements can also motivate actions and behaviour by providing 
feedback and visualise individual progress. For example, points and leader boards may set the frame for what is considered desirable actions, such as running, and allow individuals' compare their performances with themselves or with others.

Game elements that encapsulate game like conditions in non-game contexts, labelled underlying dynamics here, are very different from the characteristics of surface elements. Most games employ some form of narrative or overarching story to engage the player through fantasy and suspense (Mont et al., 1999). For example, in Space Invaders, which is one of the earliest video games, players defeat waves of aliens. A narrative is also deployed in many gamification initiatives (Langer et al., 2013). For example, the smart phone application called "zombies, run!" invites the runner to a fictive world overtaken by zombies whereby the runner is engaged in challenging missions. Other game elements that create game like conditions include trial and error (or freedom to fail), a sense of progression and multiple pathways.

The idea of multiple lives is often deployed in games to allow the player to play over and over again and succeed. This underlying dynamic of trial and error (or freedom to fail) allows players to pursue certain actions without the fear of causing irreversible damage to themselves or others. Progression is another dynamic attribute used in games to inform the player about their development, e.g. game levels, that creates a sense of direction trough the game. In many games, players have to complete tasks (e.g. solving a puzzle) to access the next level. The notion of multiple pathways is also deployed in games and allows the player to choose between various characters or game tracks. Attributes in games that create game like conditions in non-game contexts are closely related to the third category of game elements, game experience.

Game experience includes attributes in games that create game like experiences, e.g. challenges, competition and enjoyment, in non-game contexts. Games typically challenge players to complete difficult tasks or missions (Koster, 2004). Games may also involve some form of competition that engage and motivate players to compete with other players. Another typical experience that games can provoke is a sense of fun or enjoyment. Having introduced the gamification concept with particular focus on various game elements, its deployment in teaching and learning contexts is presented in the next section.

\subsection{Gamification in Education: An Analytical Framework}

Gamification is widely deployed in education settings (Dicheva et al., 2015). In such contexts, the most commonly used game elements are point systems, levels and leaderboards. The use of such game elements in pedagogical processes can engage students in challenging activities (e.g. online tests), which provide students with feedback during learning. Such feedback is a form of formative assessment. Gamification used in this way is, however, criticized for not adding value to teaching and learning (Lee \& Hammer, 2011). For example, points are 
also commonly used in exams and overall achievements in a course are graded. By implication, the use of point system and associated surface elements is therefore criticized and does not recognized the full potential for gamification in education.

A study of gamification in teaching and learning contexts by Stott and Neustaedter (2013) points to additional game elements beyond points and leaderboards; these are freedom to fail, feedback, progression and story-telling. In educational settings, trial and error may encourage students to engage in learning activities, make decisions on what to explore, and crucially to be exposed to consequences of making poor decisions (Kapp, 2012). This form of freedom to fail approach can be useful during a course to allow students to engage in the process of learning and not only focusing on the end-result. Trial and error is closely related to feedback and sense of progression. Feedback is commonly used in education to inform students how well they are doing and what they need to improve. Feedback can also be given by the students to inform the teacher about their experience of the course and how the course can be improved. Feedback is therefore an interactive two-way process. In education, feedback between teacher and students that are provided during the process of learning, also known as formative assessment, offers opportunities for both teacher and students to improve during a course. In games, however, feedback tends to be very frequent and targeted compared to that of feedback in education (Kapp, 2012). Therefore, feedback as game element can be used in education to promote frequent and targeted feedback to students. Feedback can also help create a sense of progression.

A sense of progress can be created in education to inform the students about their performance and progress in a course. Used differently, a learning process can develop progressively and involve increasingly challenging tasks. This idea of progression was deployed in a teaching course at the University of Arizona (Lee, 2012). Progression was used here to allow students to move from one learning objective to another. Here, learning objectives include 1) identifying, understanding and remembering, 2) analyzing, evaluating, critiquing and summarizing, and 3) composing, creating and planning. As such, these learning objectives were organized to assist progressive development of skills.

This literature review identifies multiples game elements and show that gamification is variously deployed in various educational settings as a means to motivate and engage students. Dicheva et al. (2015) argue that gamification that has been purposively deployed in education is typically found in teaching computer science disciplines. In contrast, in their analysis of gamification in education, Stott and Neustaedter (2013) found that the gamification concept resonates with modern pedagogical practices. This suggests that gamification is far from novel in such settings. However, there is paucity in the literature on gamification in (higher) education on how we might understand gamification as a pedagogy to motivate and engage students. An analytical framework was therefore developed 
to analyze gamification in education practices (Table 1).

The analytical framework in Table 1 was used as part of this project in order to explain gamification in education practices. The following aspects of teaching and learning were identified and further explored in light of the gamification concept, these are cognitive, performative and normative (see Table 1). Cognitive aspects involve notions of psychology and the idea of mental models. Both students and teacher has mental models associated with how teaching and learning proceed in practice. Performative aspects involve the process of doing. In other words, both teachers and students are affected by each other's doings. Normative aspects relate to reflective evaluations, e.g. understandings of what may constitute good or bad approaches to teaching and learning.

\section{Teaching Sustainable Marketing Management}

This section presents findings from the empirical study on gamification in an advanced course on sustainable marketing management at the Swedish University of Agricultural Science. The course is offered to students in agricultural- and environmental economics and management master's programme. The prerequisites for this course require students to have an advanced understanding (120 credits) in business administration. The course evaluations show that students enjoy this course. The learning objective of this course is to address sustainability issues from a marketing perspective. A perspective on sustainable development is therefore deployed: sustainable development cannot be fully understood from one disciplinary perspective (e.g. economics or business administration). As such, the course departs from traditional perspectives in business studies with particular reference to marketing management. It then introduces theories, concepts and empirical examples from business studies and marketing contexts, which offers multiple perspectives on aspects of sustainable development. As such, the course brings multiple perspectives into the teaching activities, and students are encouraged to be actively engaged in these activities. The pedagogical

Table 1. Analytical framework on learning and the use of gamification elements inspired by Bloom's taxonomy (1956) of learning outcomes.

\begin{tabular}{cccc}
\hline $\begin{array}{c}\text { Analytical } \\
\text { categories }\end{array}$ & Cognitive & Performative & Normative \\
\hline Meaning & $\begin{array}{c}\text { Understanding, mental } \\
\text { models of teacher and } \\
\text { students regarding how } \\
\text { they think about teaching } \\
\text { and learning }\end{array}$ & $\begin{array}{c}\text { Doing, what students } \\
\text { (and teacher) do in a } \\
\text { teaching session }\end{array}$ & $\begin{array}{c}\text { Assessment, reflective } \\
\text { evaluation, on good } \\
\text { and bad teaching and } \\
\text { learning }\end{array}$ \\
Gamification in & $\begin{array}{c}\text { Gamification can be used } \\
\text { in education to surprise } \\
\text { and disrupt students, } \\
\text { which in turn may open up } \\
\text { their mental models about } \\
\text { teaching and learning }\end{array}$ & $\begin{array}{c}\text { Gamification can be } \\
\text { used in education to } \\
\text { develop new forms of } \\
\text { practices of teaching } \\
\text { and learning }\end{array}$ & $\begin{array}{c}\text { Students that enjoy } \\
\text { teaching session may } \\
\text { also stay motivated } \\
\text { and engaged } \\
\text { throughout }\end{array}$ \\
\hline
\end{tabular}


processes through which teaching and learning occurs include lectures, seminars, case based learning, external lectures and an exploratory investigation. These teaching activities are explored below with particular focus on the use of game elements in these.

\section{Teaching Activities and Game Elements}

The lectures are developed and performed by the teacher of this course. These lectures introduce theories and concepts relating to sustainable marketing management. These lectures are traditional in the sense that the teacher "talks to the students" and introduce as well as explains theoretical frameworks and concepts relating to sustainable development from a marketing perspective. For example, the notion of the triple bottom line is displayed as part of the course where environmental, social and economic factors jointly set the framework for sustainable marketing objectives.

In the seminars students engage and critically reflect on articles relating to business studies, marketing and sustainable development. Students are also given instructions to write and submit a critical reflection as preparation for the seminars. In this way, seminars is a form of challenge where by students has to be actively engaged. At the seminars, the students are engage in dialogue with fellow students and the teacher. The teacher's role at the seminar is to facilitate dialogue. In these seminars, the articles form the basis for discussion whereby the participants present their reflections. As such, the seminars offer opportunity for multiple pathways to be explored as well as instant feedback between students including the teacher.

In case-based learning, a case study can be used for engaging students to explore a complex problem situation (Mark-Herbert, 1999). A case study is a form of narrative or story that creates the vehicle for learning. Case study material is provided to the students along with instructions to guide the students to conduct an initial analysis as part of individual preparations (see Figure 1). As such, the case study represents a challenge for the students and active engagement is

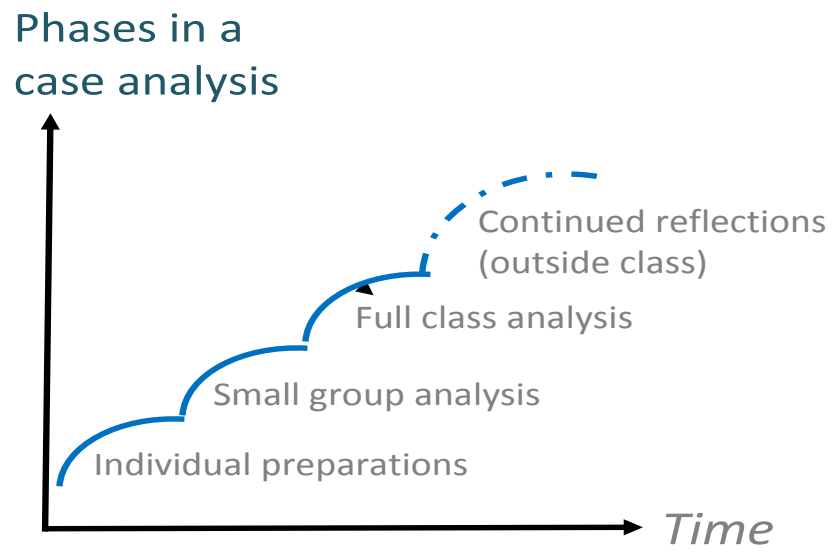

Figure 1. Learning phases in case based analysis (Mark-Herbert, 1999, 11). 
required of them to explore and analyze the case study. In the subsequent analytical phases, students meet in class where smaller groups discuss their individual analysis as preparation for full class dialogue. The teacher acts as facilitator in the full class dialogue where students discuss the case and receive instant feedback from participants in the dialogue.

Thus, case based learning can have several advantageous. More specifically, the case study analysis helps participants to understand that complex problems do not have a single or obvious answer. Rather, case based learning shows that students make different interpretations of the empirical situation leading to unique analysis every time a case is used. Case studies are also useful in that they allow students to explore and make use of theoretical frameworks, concepts and ideas in relation to real world situations. Case studies may also offer grounds to train several generic competencies related to sustainable development (Wiek et al., 2011: p. 206) such as system thinking, anticipatory, strategic, normative and interpersonal competencies. However, working with case based learning requires careful preparations for both the teacher (to write and preparing case study materials) and students to read and analyze the case in advance of the teaching session. It also requires active participation and dialogue between all the participants, which may not suit all type of students or teachers.

Another pedagogical activity in this course is external lectures. In these instances, individuals with particular knowledge and experience relating to sustainable development and marketing are invited to share their perspectives. External lecturers are invited from firms, organizations and universities. They bring perspectives rooted in different disciplines (e.g. environmental management, sales, sociology, and innovation studies) as well as insights gained from different business contexts, e.g. energy, agriculture and forestry. In aggregate, external lectures offers students different narratives relating to sustainable development in relation to sustainability working in various contexts.

As part of completing the course, the students also conduct a group project investigation in which they identify and analyze a real world sustainability initiative. As any investigation, it presents students with a challenge to explore ways of addressing sustainability issues in a particular context. The investigation develops progressively as students learn more about their selected topic. The project is also a process that involves trial and error as well as feedback from fellow students and the teacher.

This empirical illustration shows how gamification is deployed in a case of management education for sustainable development. The teaching activities in this course include multiple game elements, notably challenge, multiple pathways, trial-and-error, feedback, narrative and progression. These game elements motivate students to be actively engaged in teaching and learning activities. Notion of interdisciplinary working is promoted in this course as perspectives on sustainable development from different disciplines are brought into the teaching activities. The deployment of game elements in management education and its 
potential to promote interdisciplinary working for sustainable development is further discussed in the next section.

\section{Discussion}

Findings from case study research suggest that the gamification concept offers an interesting and useful approach to promote interdisciplinary working in the context of management education for sustainable development. Drawing on the neat definition of gamification as the use of game elements in non-game contexts (Deterding et al., 2011), we identified a plurality of such elements in a selected educational setting. The pedagogical processes of the sustainability marketing management course at SLU include seminars, learning with cases, external lectures and group project. Game elements identified in these education practices are presented in Table 2. The dynamics of game elements in education practices are assessed in terms of their contribution to learning and interdisciplinary working.

Findings from the empirical study shows that game elements can be deployed in education practices to motivate students to engage in learning activities. The use of game elements in education practices and their contribution to learning is further discussed. For instance, the use of narratives such as a case or stories from empirical contexts appears to be a useful element that motivates students to engage in the learning activity. In the sustainability marketing course, students

Table 2. Gamification in pedagogical processes.

\begin{tabular}{|c|c|c|}
\hline $\begin{array}{c}\text { Education in } \\
\text { practice }\end{array}$ & Game elements & $\begin{array}{l}\text { Contribution to learning and } \\
\text { interdisciplinary working }\end{array}$ \\
\hline Seminars & $\begin{array}{c}\text { Challenge, multiple } \\
\text { pathways, trial-and-error, } \\
\text { feedback }\end{array}$ & $\begin{array}{l}\text { Encourages students to critically } \\
\text { reflect on aspects of sustainable } \\
\text { development; the seminar readings } \\
\text { allow students to explore multiple } \\
\text { pathways and involve trial-and-error } \\
\text { including frequent and targeted feedback. }\end{array}$ \\
\hline $\begin{array}{l}\text { Learning with } \\
\text { cases }\end{array}$ & $\begin{array}{l}\text { Challenges, narrative, } \\
\text { role-play, trial-and-error, } \\
\text { feedback, enjoyment }\end{array}$ & $\begin{array}{l}\text { Cases consist of a story that is used as the } \\
\text { vehicle for learning; cases allow students to } \\
\text { explore challenges from multiple } \\
\text { perspectives using role-play }\end{array}$ \\
\hline $\begin{array}{l}\text { External } \\
\text { Lectures }\end{array}$ & $\begin{array}{c}\text { Narrative, multiple } \\
\text { pathways, enjoyment }\end{array}$ & $\begin{array}{l}\text { External lectures in aggregate offers multiple } \\
\text { narratives from a variety of disciplines (e.g. } \\
\text { innovation studies, environmental } \\
\text { management) and working contexts, e.g. } \\
\text { forestry, energy and food sectors }\end{array}$ \\
\hline Group project & $\begin{array}{c}\text { Challenges, } \\
\text { trial-and-error, feedback, } \\
\text { progression }\end{array}$ & $\begin{array}{l}\text { Students conduct an investigation that allow } \\
\text { students to explore aspects of sustainable } \\
\text { development. Exploratory enquires develop } \\
\text { progressively based on trial-and-error, } \\
\text { feedback and reflection. }\end{array}$ \\
\hline
\end{tabular}


were presented with narratives from external lectures as well as in the materials that form the basis for case based learning. Narratives allow students to reflect on complex issues (e.g. aspects of sustainable development) and explore possible solutions in dialogue with others, often teacher and fellow students. As such, narratives, including the exploratory and dialogue based nature of the teaching sessions may expose students to multiple pathways. In education for sustainable development, multiple pathways in terms of ways of understanding and addressing sustainability issues rather than single answers or solutions are emphasized.

Challenges are used in education practices to engage students from the outset by placing the focus of learning upon them. For example, seminars challenge the student to read and critically reflect on the readings as well as sharing their thoughts and understanding in dialogue with fellow students and the teacher. The notion of progression is a third element identified in the education practices. In creating a sense of progression students are faced an increasing number and level of difficulties. For example, the process of the course itself moves from understanding concepts and ideas to the application of concepts and ideas to stories from empirical contexts as well as in conducting an investigation. As such, the course requires students to develop declarative knowledge, which is assessed via an exam, as well as functional knowledge, which is assessed via the completion of an investigation.

This analysis and discussion of gamification in education practices shows how gamification can be deployed to promote interdisciplinary working in teaching sessions. More specifically, the sustainable marketing management course departs from traditional or dominant perspectives in business studies and marketing management. It offers nuanced theories and concepts that open up ways of understanding issues of sustainable development. Students are exposed to, and critically engage with, different perspectives rooted in a variety of disciplines (e.g. innovation studies, environmental management) as well as stories from empirical contexts. In these educational practices, e.g. seminars, cases, students interact with fellow students, the teacher as well as students from other disciplines to explore complex issues as well as ways to understand and resolve these.

Using the analytical framework developed in Section 3, the education practices described in Section 4 were analyzed. Table 3 shows how gamification works in practice; in terms of what such approaches do in teaching sessions with particular reference to the role of teacher and students.

This study shows that gamification in education practices are more than online applications. This insight resonates with the work by Stott and Neustaedter (2013) in that gamification forms part of nuanced and creative pedagogic practices. Indeed, education practices can deploy a variety of game elements to motivate students and engage them in learning activities. As such, this study contributes to the potential use of gamification in education beyond surface elements, e.g. points and leaderboards. 
Table 3. Gamification in education practice.

\begin{tabular}{|c|c|c|c|}
\hline $\begin{array}{l}\text { Gamification in } \\
\text { education } \\
\text { practices }\end{array}$ & Cognitive & Performative & Normative \\
\hline Seminars & $\begin{array}{l}\text { The exploratory and } \\
\text { dialog-based nature of } \\
\text { seminars require active } \\
\text { (and not passive) } \\
\text { students }\end{array}$ & $\begin{array}{l}\text { Students perform } \\
\text { critical reflections via } \\
\text { readings and dialogue; } \\
\text { teacher act as } \\
\text { facilitator }\end{array}$ & $\begin{array}{l}\text { The interactive and } \\
\text { exploratory nature is } \\
\text { perceived as good } \\
\text { teaching and learning } \\
\text { practice by the } \\
\text { students }\end{array}$ \\
\hline $\begin{array}{l}\text { Learning with } \\
\text { cases }\end{array}$ & $\begin{array}{l}\text { Its exploratory and } \\
\text { story-based nature } \\
\text { require students to } \\
\text { confront multiple } \\
\text { perspectives and } \\
\text { pathways associated } \\
\text { with a real-world } \\
\text { challenge }\end{array}$ & $\begin{array}{l}\text { Students perform } \\
\text { critical reflections via } \\
\text { readings and dialogue; } \\
\text { teacher ac as facilitator }\end{array}$ & $\begin{array}{l}\text { The interactive and } \\
\text { exploratory nature is } \\
\text { perceived as good } \\
\text { teaching and learning } \\
\text { practice by } \\
\text { the students }\end{array}$ \\
\hline External lectures & $\begin{array}{l}\text { Students are exposed to } \\
\text { stories rooted in } \\
\text { various disciplines } \\
\text { from different contexts }\end{array}$ & $\begin{array}{c}\text { Students are } \\
\text { encourage to engage in } \\
\text { dialogue with external } \\
\text { lectures; teacher } \\
\text { becomes largely } \\
\text { passive }\end{array}$ & $\begin{array}{l}\text { External lectures are } \\
\text { perceived as good } \\
\text { education practice by } \\
\text { the students }\end{array}$ \\
\hline Group project & $\begin{array}{l}\text { Students take } \\
\text { responsibility for } \\
\text { their own learning by } \\
\text { conducting an } \\
\text { investigation }\end{array}$ & $\begin{array}{l}\text { Students perform an } \\
\text { investigation; teacher, } \\
\text { including students, } \\
\text { support and facilitate } \\
\text { progress of the } \\
\text { investigation }\end{array}$ & $\begin{array}{l}\text { Conducting an } \\
\text { (empirical) } \\
\text { investigation is } \\
\text { perceived as good } \\
\text { education practice by } \\
\text { the students }\end{array}$ \\
\hline
\end{tabular}

\section{Conclusions}

This paper shows how gamification can be deployed in education practices to motivate and engage students' learning activities that involve interdisciplinary working associated with issues relating to sustainable development. More specifically, game elements beyond points system, levels and leaderboards (e.g. challenges, narrative, multiple pathways and sense of progress) can be deployed in teaching sessions to elevate the level of student engagement. Such game elements can be used in education practices (e.g. seminars, cases) to engage students in interdisciplinary working. For example, stories can be used in teaching sessions to envisage complex issues of sustainable development and engage students to explore multiple pathways to address these. As such, perspectives rooted in different disciplines such as environmental management, sales, sociology, and innovation studies and how these apply to various business contexts (e.g. energy, agriculture and forestry) can be brought into teaching activities (e.g. seminars, case-based learning, external lectures and exploratory investigations) to explore context-bound aspects of sustainable development. However, interdisciplinary working in such context requires participants to be actively engaged in these 
activities. It is in such instances that gamification can be deployed as a pedagogic approach to create cognitive, performative and normative learning outcomes.

Cognitive affects are for example the use of game elements that surprise and disrupt students and challenge their mental models on teaching and learning, and may create opportunities for nuanced ideas of teaching and learning. Performative affects are for example deployment of game elements to create conditions for desirable actions and behavior, e.g. dialogue based and exploratory seminars that create conditions for students to actively engage in these. Normative affects are for example the use of game elements to challenge traditional learning and create fun and interactive learning perceived by students as good teaching and learning practice. Seen in this way, gamification in management education for sustainable development can be used to motivate students to engage in deep approach to learning and help them to attain both declarative and functional knowledge. It offers a pedagogic approach to elevate students' engagement, which can be necessary to promote interdisciplinary working in management education for sustainable development.

\section{Acknowledgements}

This project has been made possible thanks to funding for a visiting scholar opportunity for Dr. Matthew Cook. We would like to express our gratitude for the August T Larsson funding.

\section{References}

Biggs, J., \& Tang, C. (2011). Teaching for Quality Learning at University (4th ed.). Berkshire: McGraw Hill, Open University Press.

Bloom, B. S. (ed.) (1956). Taxonomy of Education Objectives: Handbook 1. Cognitive domain, New York: Addison Wesley Longman.

Brooks, C., \& Ryan, A. (2008). Education for Sustainable Development Interdisciplinary Discussion Series Report. York: The Higher Education Academy.

Deterding, S., Dixon, D., Khaled, R., \& Nacke, L. (2011). From Game Design Elements to Gamefulness: Defining “Gamification”. In A. Lugmayr, H., Franssila, C. Safran, \& I. Hammouda (Eds.), MindTrek 2011 (pp. 9-15). New York: ACM. https://doi.org/10.1145/2181037.2181040

Dicheva, D., Dichev, C., Agre, G., \& Angelova, G. (2015). Gamification in Education: A Systemic Mapping Study. Educational Technology \& Society, 18, 75-88.

Erenli, K. (2013). The Impact of Gamification: Recommending Education Scenarios. iJET, 8, 15-21, in Special Issue 1: ICL2012.

Gibbons, M., Limoges, C., Nowotny, H., Schwartzman, S., Scott, S., \& Trow, M. (1994). The New Production of Knowledge: The Dynamics of Science and Research in Contemporary Societies. London: Sage.

Guy, S. (2006). Designing Urban Knowledge: Competing Perspectives on Energy and Buildings. Environment and Planning C: Government and Policy, 24, 645-659.

https://doi.org/10.1068/c0607j

Guy, S., \& Farmer, G. (2001). Reinterpreting Sustainable Architecture: The Place of Technology. Journal of Architectural Education, 54, 140-148. 
https://doi.org/10.1162/10464880152632451

Guy, S., \& Shove, E. (2000). A Sociology of Energy, Buildings and the Environment: Constructing Knowledge, Designing Practice. London and New York: Routledge.

Hamari, J., Koivisto, J., \& Sarsa, H. (2014). Does Gamification Work?-A Literature Review of Emperical Studies on Gamification. 47 th Hawaii International Conference on System Science, 3025-3034

http://people.uta.fi/ kljuham/2014-hamari_et_al-does_gamification_work.pdf

Kapp, K. M. (2012). Games, Gamifiation, and the Quest for Learner Engagement. Talent Development, 66, 64-68.

Koster, R. (2004). A Theory of Fun for Game Design. New York: Paraglyph Press.

Langer, R., Hancock, M., West, A. H., \& Randall, N. (2013). Applications as Stories. In ACM SIGCHI Conference on Human Factors in Computing Systems. Paris: CHI. https://chi2013.acm.org/

Lee, J., \& Hammer, R. J. (2011). Gamification in Education: What, How, Why Bother? Academic Exchange Quarterly, 15, 146.

Lee, S. (2012). The Multiplayer Classroom: Designing Coursework as a Game. Boston, MA: Cengage Learning.

Longhurst, J. (2014). Education for Sustainable Development: Guidance or UK Higher Education Providers.

http://www.qaa.ac.uk/en/Publications/Documents/Education-sustainable-development -Guidance-June-14.pdf

Mark-Herbert, C. (1999). “Case metodik” en pedagogisk skrift, SLU Pedagogiska rapporter (nr. 45). [Case Method, a Pedagogical Report.]

https://pub.epsilon.slu.se/14716/

Orr, D. (2002). The Nature of Design: Ecology, Culture and Human Intention. New York: Oxford University Press.

Rockström, J., Steffen, W., Noone, K., Persson, Å., Chapin III, F. S., Lambin, E., Lenton, T. M., Scheffer, M., Folke, C., Schellnhuber, H., Nykvist, B., De Wit, C. A., Hughes, T., van der Leeuw, S., Rodhe, H., Sörlin, S., Snyder, P. K., Costanza, R., Svedin, U., Falkenmark, M., Karlberg, L., Corell, R. W., Fabry, V. J., Hansen, J., Walker, B., Liverman, D., Richardson, K., Crutzen, P., \& Foley, J. (2009). Planetary Boundaries: Exploring the Safe Operating Space for Humanity. Ecology and Society, 14, 32.

http://www.ecologyandsociety.org/vol14/iss2/art32/ https://doi.org/10.5751/ES-03180-140232

Stott, A., \& Neustadter, C. (2013). Analysis of Gamification in Education. Simon Fraser University. (Unpublished Material) http://clab.iat.sfu.ca/pubs/Stott-Gamification.pdf

Wiek, A., Withycombe, L., \& Redman, C. (2011). Key Competencies in Sustainability: A Reference Framework for Academic Program Development. Sustainable Science, 6, 203-218. https://doi.org/10.1007/s11625-011-0132-6 